\title{
Effect of annealing on creep behavior, hardness, roughness and electrochemical corrosion parameters of $\mathrm{Co}$ - $\mathrm{Cr}$ based alloy
}

\author{
A. El-Bediwi ${ }^{1}$, Eman Kashita ${ }^{2}$, Salah. M .M.Salman ${ }^{2,3}$ \\ ${ }^{1}$ Physics Department, Faculty of Science, Mansoura University, Egypt \\ ${ }^{2}$ Educational Services, Qassim University, Ministry of High Education, Kingdom of Saudi Arabia \\ ${ }^{3}$ Physics Department, Faculty of Science, Helwan University, Ain-Helwa \\ baker_elbediwi@yahoo.com
}

ABSTRAT

In the present work, the effect of annealing on creep behavior, hardness, maximum shear stress, roughness and electrochemical corrosion parameters of commercial $\mathrm{Co}_{64} \mathrm{Cr}_{29} \mathrm{Mo}_{6.5} \mathrm{~A}_{0.5}(\mathrm{~A}=\mathrm{C}, \mathrm{Si}, \mathrm{Fe}$, and $\mathrm{Mn})$ dental alloy from Travagliato (BS) - Italy have been studied and analyzed. Creep behavior was studied by indentation and stress exponent was determined by Mulheam-Tabor method. The results show that, Vickers hardness of $\mathrm{Co}_{64} \mathrm{Cr}_{29} \mathrm{Mo}_{6.5} \mathrm{~A}_{0.5}$ alloy decreased but roughness parameters varied after annealing for two hours at 700,800 and $900{ }^{\circ} \mathrm{C}$. Also the corrosion resistance in $0.5 \mathrm{M}$ $\mathrm{HCl}$ of $\mathrm{Co}_{64} \mathrm{Cr}_{29} \mathrm{Mo}_{6.5} \mathrm{~A}_{0.5}$ alloy is increased but the corrosion rate with $0.5 \mathrm{M} \mathrm{HCl}$ is decreased after annealing compared to normal alloy.

Key words: - creep, hardness, roughness, corrosion parameters

\section{INTRODUCTION}

Cobalt-chromium alloys are widely used in prosthetic dentistry for fabrication of removable partial dentures and some fixed prosthetic appliances. Advantages of these dental alloys for casting prosthetic appliances are their low weight and good mechanical properties, such as great hardness, strength, resistance to tarnish and high temperatures and also resistance to corrosion. Cobalt-chromium based alloys have excellent corrosion resistance [1-5]. These alloys are mainly used for the fabrication of removable partial dentures because of their outstanding mechanical properties [6]. Since the beginning of the 20th century, Co-Cr-Mo alloys had used as cutting tools, valves of safety, turbines and strategic materials. They are also employed in bolts, screws and, in particular, in orthodontic prostheses [7-9]. The aim of this work was to study the effect of annealing on electrochemical corrosion parameters, indentation creep, hardness and roughness of commercial $\mathrm{Co}_{64} \mathrm{Cr}_{29} \mathrm{Mo}_{6.5} \mathrm{~A}_{0.5}$ dental alloy.

\section{MATERIAL AND METHODS}

The specimen used in the present work is a commercial $\mathrm{Co}_{64} \mathrm{Cr}_{29} \mathrm{Mo}_{6.5} \mathrm{~A}_{0.5}(\mathrm{~A}=\mathrm{C}, \mathrm{Si}, \mathrm{Fe}, \mathrm{Mn})$ alloy from Travagliato (BS) Italy were annealed at 700,800 and $900{ }^{\circ} \mathrm{C}$ in furnace and leave in for two hours. The specimens were prepared in convenient shape for all tests such as roughness, Vickers microhardness and electrochemical corrosion behavior. Microhardness test of used specimens were conducted using a digital Vickers microhardness tester, (Model FM-7, Tokyo, Japan), applying a load of $100 \mathrm{gf}$ for 5 seconds via a Vickers diamond pyramid. The roughness of used samples were measured by using surface roughness measurements device (S.J 201.P). For measuring corrosion parameters, the potentiodynamic current versus potential curves were recorded by changing the electrode potential automatically from -1500 to $500 \mathrm{mV}$ at a scan rate of $5 \mathrm{mV} / \mathrm{s} 1$ using Voltage lab PGZ 100 (Germany PC 3-300) and a computer with Volta Master 4 software (Germany frame work version 7.08) for calculations. For indentation creep, Vickers microhardness tester at different load and time was used. There exists a linear relationship between indentation time and hardness for all conditions. The slope of the resultant lines according Mulheam-Tabor method is $-\left(n+\frac{1}{2}\right)$ where $\mathrm{n}$ is the stress exponent [10].

\section{RESULTS AND DISCUSSION}

\subsection{Creep behavior}

Creep behavior of $\mathrm{Co}_{64} \mathrm{Cr}_{29} \mathrm{Mo}_{6.5} \mathrm{~A}_{0.5}$ alloy was studied by indentation method performed at room temperature. Figure (1a) shows the indentation creep data where the indentation length is plotted versus the indentation time at constant loads $(100,200$ and $300 \mathrm{~g})$. The indentation length increased with the loading time and the applied load increased. The curves shown in Figure (1a) consist of two stages similar to an ordinary creep curve. The first stage of the curve records an increase in the indentation length with loading time followed by a steady-state region where indentation sizes increase linearly with time. Fracture of the specimen dose not occurs and it is not possible to record a third stage of the curve as opposed to what happens in an ordinary creep test because the hardness test is a compression test.

In the Mulheam-Tabor method, Figure (1b), Vickers hardness number of $\mathrm{Co}_{64} \mathrm{Cr}_{29} \mathrm{Mo}_{6.5} \mathrm{~A}_{0.5}$ alloy before and after annealing for different temperature at two hours is plotted versus indentation time on log-log scale for the indentation data. The stress exponent values of $\mathrm{Co}_{64} \mathrm{Cr}_{29} \mathrm{Mo}_{6.5} \mathrm{~A}_{0.5}$ alloy before and after annealing are given in Table (1). The exponent values are in the range of 21.73 to 13.52 depending on annealing temperature of used alloy. The change in stress exponent values are attributable to microstructural features, (changing in matrix alloy such as lattice parameters, solid 
solution, size and distribution of strengthening phases and intermetallic phases) and that is agree with pervious results [11-13]. The grain boundary decreased with increasing the grain size, which dislocation movement affecting on stress exponent values [14].

Table 1:- Stress exponent of $\mathrm{Co}_{64} \mathrm{Cr}_{29} \mathrm{Mo}_{6.5} \mathrm{~A}_{0.5}$ alloy before and after annealing

\begin{tabular}{|c|c|}
\hline Alloys & Stress exponent \\
\hline Based alloy & 21.73 \\
\hline $700{ }^{\circ} \mathrm{C}$ & 16.84 \\
\hline $800{ }^{\circ} \mathrm{C}$ & 14.65 \\
\hline $900{ }^{\circ} \mathrm{C}$ & 13.52 \\
\hline
\end{tabular}
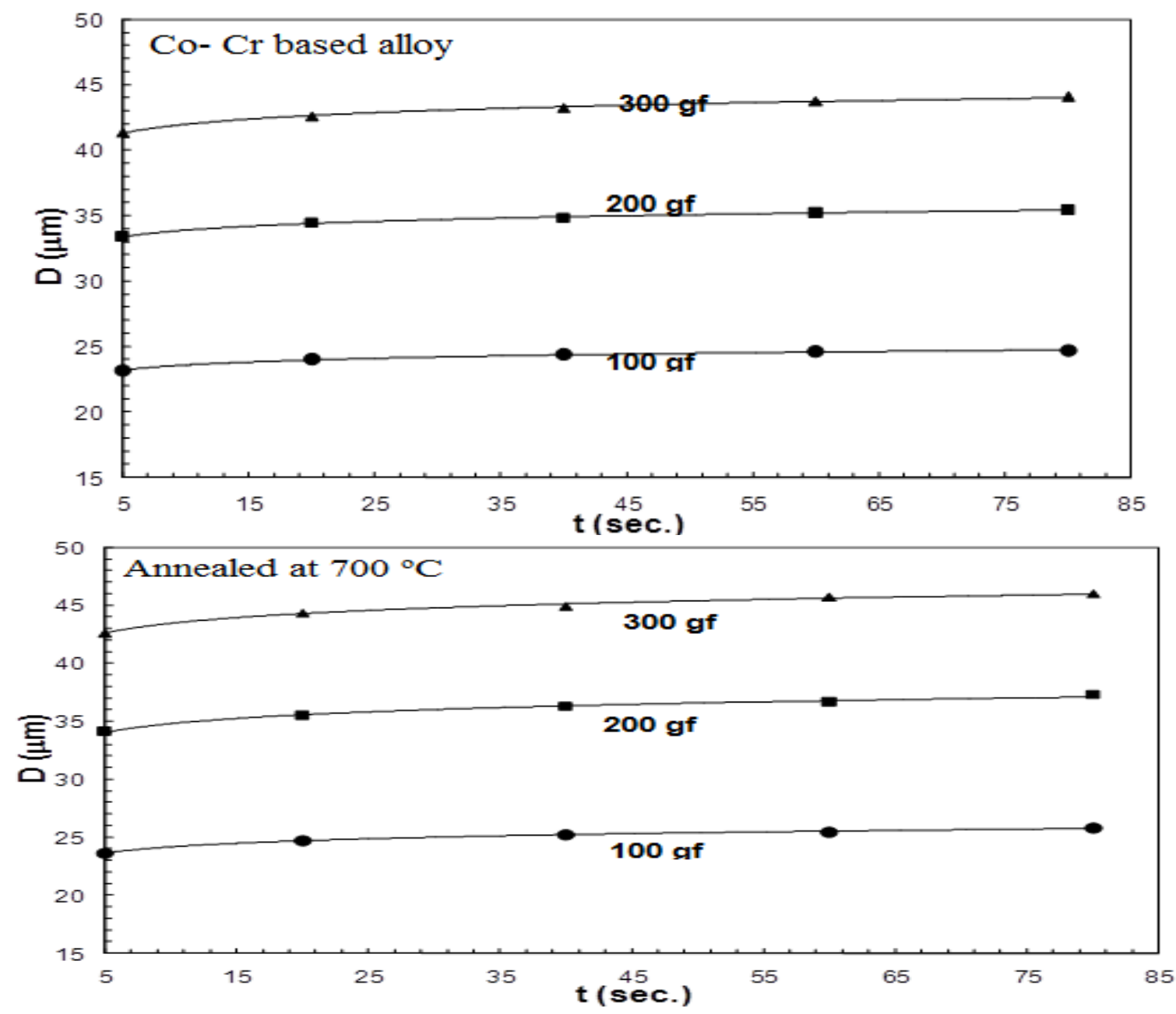

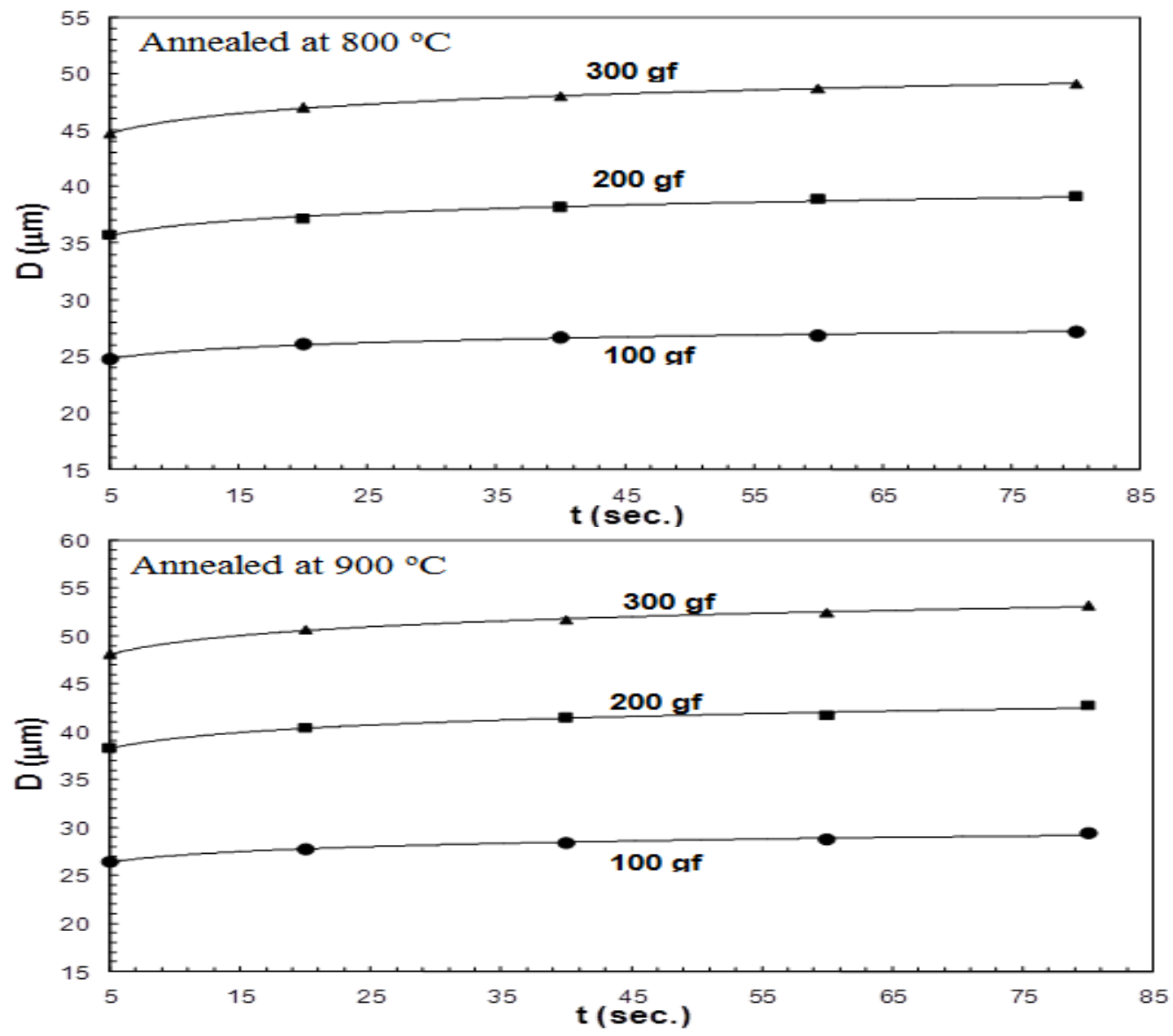

Fig. 1a:-the indentation length is plotted versus the indentation time 

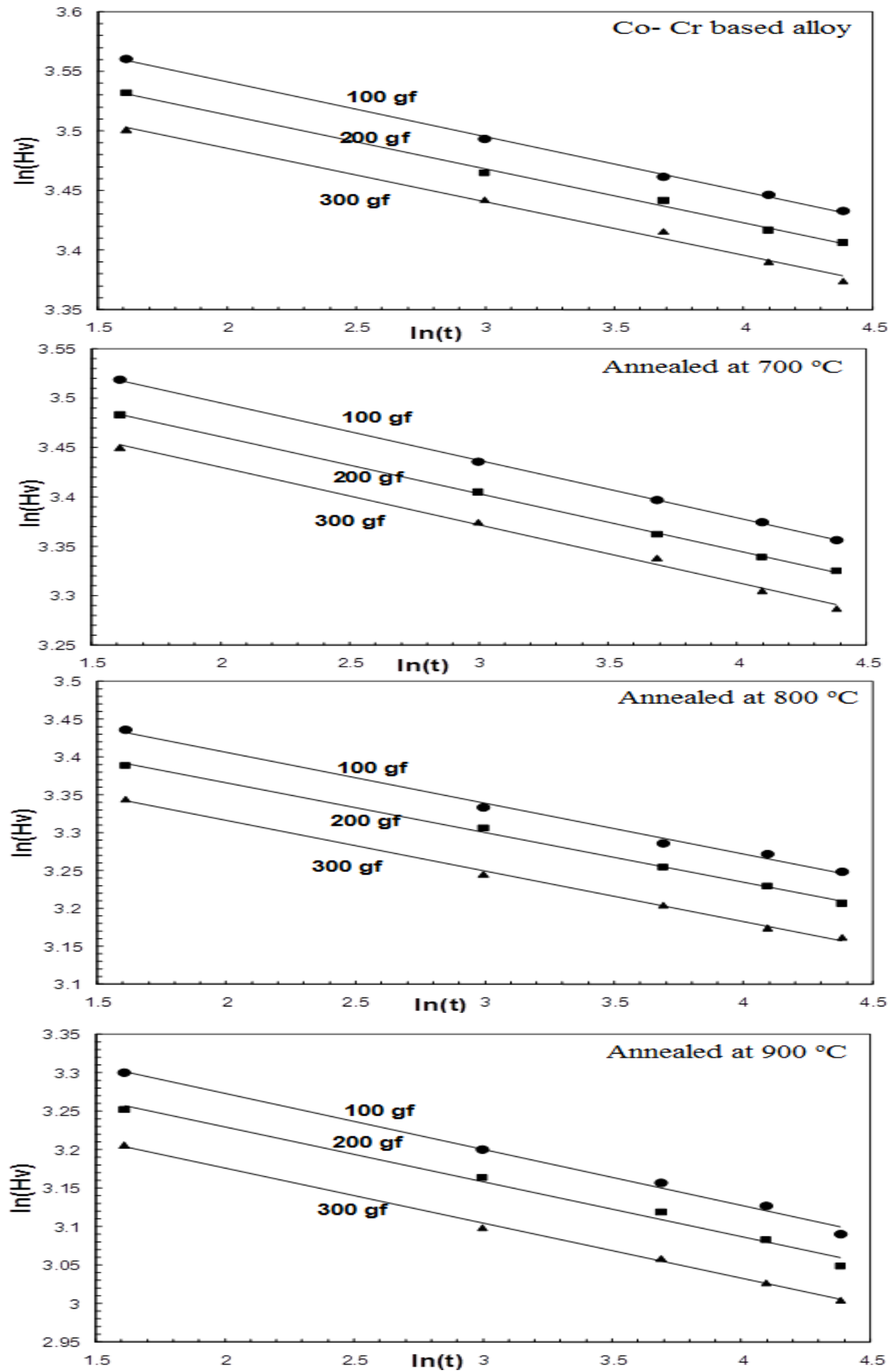

Fig. 1b:- Vickers hardness versus indentation time on log-log scale 


\subsection{Vickers hardness}

The microhardness number was conducted using a digital Vickers microhardness tester, applying a load of $100 \mathrm{~g}$ for $5 \mathrm{~s}$, for $\mathrm{Co}_{64} \mathrm{Cr}_{29} \mathrm{Mo}_{6.5} \mathrm{~A}_{0.5}$ alloy. Vickers hardness value of $\mathrm{Co}_{64} \mathrm{Cr}_{29} \mathrm{Mo}_{6.5} \mathrm{~A}_{0.5}$ alloy before and after annealing at 700,800 and $900{ }^{\circ} \mathrm{C}$ for two hours is listed in Table 2. Vickers hardness value of $\mathrm{Co}_{64} \mathrm{Cr}_{29} \mathrm{Mo}_{6.5} \mathrm{~A}_{0.5}$ alloy decreased after annealing. That is because annealing caused a softening in matrix alloy with eliminate the dislocations which attributed to a homogenization in composition. Also grain growth will occur with changing a bonding strength of the alloy as a result of heat treatment which reducing its hardness and that is agree with pervious results [15].

The maximum shear stress $\left(\mu_{\mathrm{m}}\right)$ value of $\mathrm{Co}_{64} \mathrm{Cr}_{29} \mathrm{Mo}_{6.5} \mathrm{~A}_{0.5}$ alloy before and after annealing was calculated [16] and then presented in Table 2.

Table 2:- Vickers hardness and maximum shear stress of $\mathrm{Co}_{64} \mathrm{Cr}_{29} \mathrm{Mo}_{6.5} \mathrm{~A}_{0.5}$ alloy before and after annealing

\begin{tabular}{|c|c|c|}
\hline Alloys & $\mathrm{H}_{\mathrm{v}} \mathrm{kg} \backslash \mathrm{mm}^{2}$ & $\mu_{\mathrm{m}} \mathrm{kg} \backslash \mathrm{mm}^{2}$ \\
\hline Based alloy & $345.1 \pm 23.21$ & 113.88 \\
\hline $700{ }^{\circ} \mathrm{C}$ & $330.9 \pm 23.64$ & 109.2 \\
\hline $800{ }^{\circ} \mathrm{C}$ & $304.8 \pm 24.77$ & 100.58 \\
\hline $900{ }^{\circ} \mathrm{C}$ & $265.9 \pm 26.42$ & 87.75 \\
\hline
\end{tabular}

\subsection{Roughness}

The roughness profiles of $\mathrm{Co}_{64} \mathrm{Cr}_{29} \mathrm{Mo}_{6.5} \mathrm{~A}_{0.5}$ alloy before and after annealing at 700,800 and $900{ }^{\circ} \mathrm{C}$ for two hours are shown in Figure 2. The average surface roughness parameter Ra along the total sliding distance and other roughness parameters of $\mathrm{Co}_{64} \mathrm{Cr}_{29} \mathrm{Mo}_{6.5} \mathrm{~A}_{0.5}$ alloy before and after annealing are listed in Table 3 . The results show, the annealing caused variation in average surface roughness parameter $\mathrm{Ra}$ and other roughness parameters. That is mean, numbers of formed cracks and/or pits during annealing are varied

\section{Table 3:- roughness parameters of $\mathrm{Co}_{64} \mathrm{Cr}_{29} \mathrm{Mo}_{6.5} \mathrm{~A}_{0.5}$ before and after annealing}

\begin{tabular}{|c|c|c|c|c|}
\hline \multirow{2}{*}{$\begin{array}{c}\text { Roughness } \\
\text { parameters }\end{array}$} & base & $700^{\circ} \mathrm{C}$ & $800^{\circ} \mathrm{C}$ & $900^{\circ} \mathrm{C}$ \\
\cline { 2 - 5 } & 1.06 & 1.12 & 1.08 & 1.07 \\
\hline Ra um & 5.84 & 6.74 & 5.58 & 5.84 \\
\hline Rz um & 1.35 & 1.43 & 1.35 & 1.34 \\
\hline Rq um & 8.84 & 10.6 & 7.37 & 7.04 \\
\hline Rt um & 2.73 & 3.48 & 2.95 & 2.41 \\
\hline Rp um & & \multicolumn{3}{|c|}{} \\
\hline
\end{tabular}

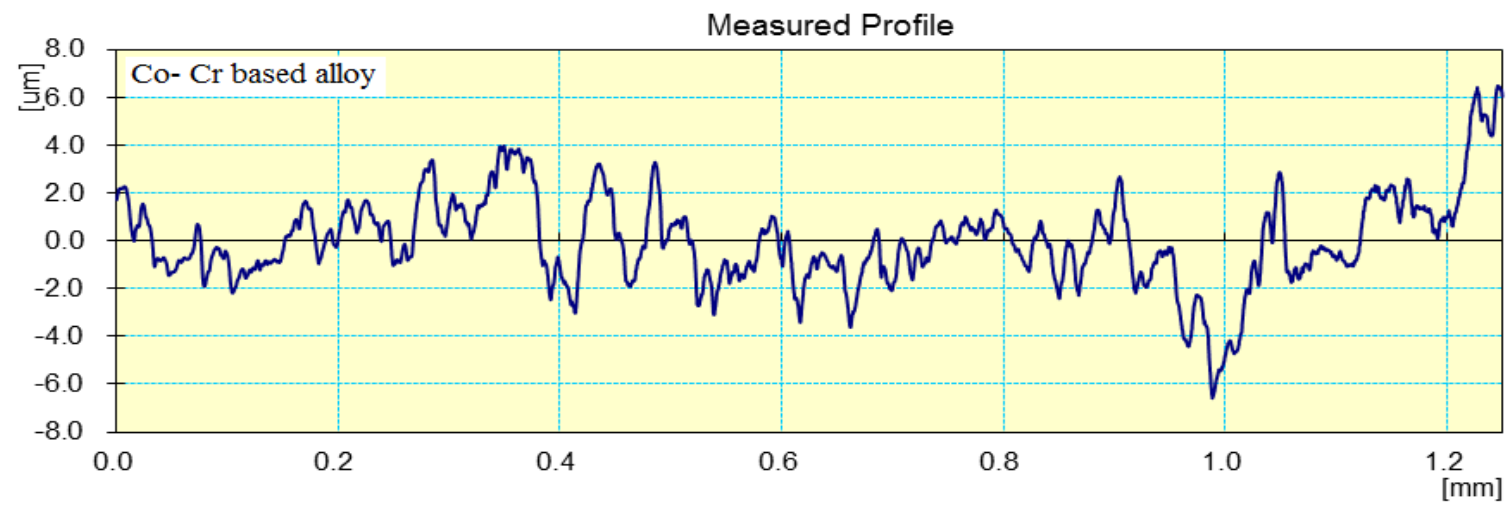



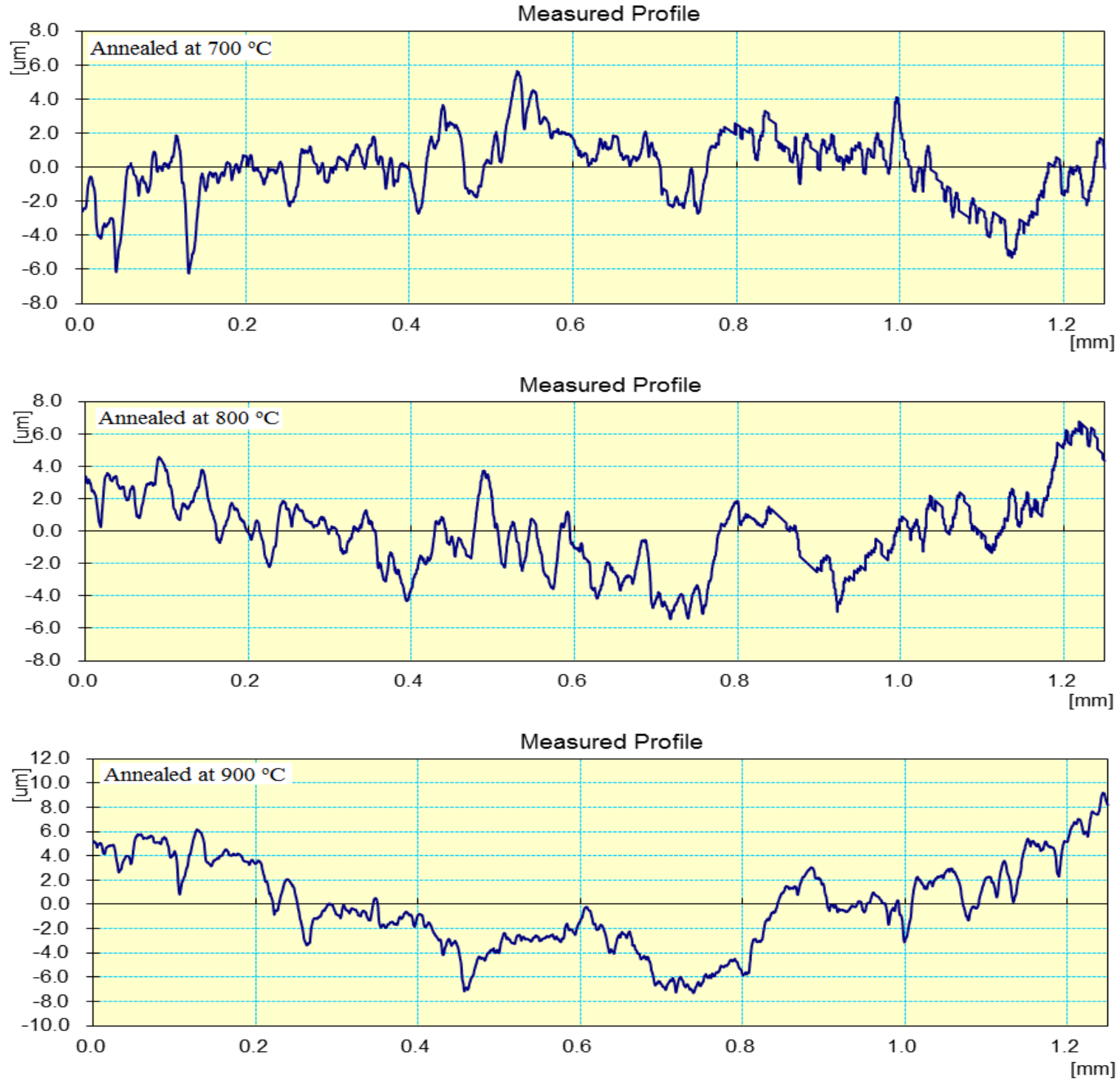

Fig. 2:- roughness profiles of $\mathrm{Co}_{64} \mathrm{Cr}_{29} \mathrm{Mo}_{6.5} \mathrm{~A}_{0.5}$ alloy before and after annealing

\subsection{Electrochemical corrosion behavior}

Table 4 presented the corrosion potential $\left(E_{\text {Corr }}\right)$, corrosion current $\left(I_{\text {Corr }}\right)$, corrosion resistance $\left(R_{p}\right)$ and corrosion rate (C.R) of $\mathrm{Co}_{64} \mathrm{Cr}_{29} \mathrm{Mo}_{6.5} \mathrm{~A}_{0.5}$ alloy before and after annealing. From these results, it is clear that the corrosion resistance in $0.5 \mathrm{M} \mathrm{HCl}$ of $\mathrm{Co}_{64} \mathrm{Cr}_{29} \mathrm{Mo}_{6.5} \mathrm{~A}_{0.5}$ alloy is increased but the corrosion rate with $0.5 \mathrm{M} \mathrm{HCl}$ is decreased after annealing. That is meant annealing caused heterogeneous microstructure with affected on microsegregation and reactivity of Co and other atoms with $\mathrm{HCl}$ solution

Table 4:- corrosion parameters of $\mathrm{Co}_{64} \mathrm{Cr}_{29} \mathrm{Mo}_{6.5} \mathrm{~A}_{0.5}$ before and after annealing

\begin{tabular}{|c|c|c|c|c|}
\hline Alloys & $\mathrm{E}_{\text {corr }} \mathrm{mV}$ & $\mathrm{I}_{\text {corr }} \mu \mathrm{A} / \mathrm{cm}^{2}$ & C. $\mathrm{R} \mathrm{mm} / \mathrm{yr}$ & $\mathrm{Rp} \mathrm{Ohm} \mathrm{\textrm {cm } ^ { 2 }}$ \\
\hline Based alloy & -341.3 & 71.9 & 0.836 & $0.69 \mathrm{E}+03$ \\
\hline $700{ }^{\circ} \mathrm{C}$ & -333.3 & 39.8 & 0.462 & $1.1 \mathrm{E}+03$ \\
\hline $800{ }^{\circ} \mathrm{C}$ & -326.4 & 42.43 & 0.494 & $1.01 \mathrm{E}+03$ \\
\hline $900{ }^{\circ} \mathrm{C}$ & -334 & 54.5 & 0.634 & $0.89 \mathrm{E}+03$ \\
\hline
\end{tabular}




\section{CONCLUSION}

The average surface roughness parameter $\mathrm{Ra}$ of $\mathrm{Co}_{64} \mathrm{Cr}_{29} \mathrm{Mo}_{6.5} \mathrm{~A}_{0.5}$ alloy increased after annealing at different temperature for two hours

1- Stress exponent and Vickers hardness values of $\mathrm{Co}_{64} \mathrm{Cr}_{29} \mathrm{Mo}_{6.5} \mathrm{~A}_{0.5}$ alloy decreased after annealing for two hours

2- Roughness parameters of $\mathrm{C}_{66} \mathrm{Cr}_{29} \mathrm{Mo}_{6.5} \mathrm{~A}_{0.5}$ alloy varied after annealing.

3- The corrosion resistance of $\mathrm{Co}_{64} \mathrm{Cr}_{29} \mathrm{Mo}_{6.5} \mathrm{~A}_{0.5}$ in $0.5 \mathrm{M} \mathrm{HCl}$ increased but the corrosion rate with $0.5 \mathrm{M} \mathrm{HCl}$ decreased after annealing.

\section{REFERENCES}

1. Lucas LC, Dale P, Buchanan R, Goll Y, Griffin D, Lemons JE, J Invest Surg, $4: 1$ (1991) 13

2. G Geis-Gerstorfer J, Sauer KH, Passler K, Int J Prosthodont, 4: 2 (1991) 152

3. Grimido NJ, Gen Dent, 49: 5 (2001) 498

4. Dong H, Nagamatsu Y, Chen KK, Tajima K, Kakigawa H, Shi S, Kozono Y, Dent Mater J, 22: 4 (2003) 482

5. Rinic N, Baucic I, Miko S, Papic M, Prohic E, Coll Antropol, 27: 2 (2003) 99

6. Anusavice KJ, Phillips, science of dental materials, $11^{\text {th }}$ ed. London: Saunders; (2003) 594

7. Gerstorfer J.G, J. Dent., 22 (1994) 247

8. Johansson B.I, Lemons J.E, Hao S.Q, Dent. Mater, 5 (1989) 324

9. Craig R.G, Powers J.M, Restorative Dental Materials. $12^{\text {th }}$ Ed., St. Louis: Mosby, (2006) 372

10. Mulhearn TO, Tabor D. J Inst Metals, 89 (1960) 7

11. Kamal M, El-Bediwi A, Lashin A.R, El-Zarka A.H, J. Mater. Eng. Performance, (2016) 1-7

12. El-Bediwi A, S. Bader S, Farag Z, Global Journal of Physics, 4: 2 (2016) 422- 439

13. El-Bediwi A, Ismail K, Kamal M, MSAIJ, 9: 2 (2013) 73-77

14. El-Bediwi A, Saad M, El-Fallel A, El-Helaly T, J. Biophys. Biomed. Sci. 2: 1 (2009) 121- 124

15. Verhoeven J.D, Fundamentals of Physical Metallurgy, Wiley, New York, (1975) 326

16. TTimoshenko S, Goodier J, Theory of Elasticity, 3rd ed.; McGraw- Hill: New York, (1970) 407

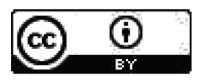

This work is licensed under a Creative Commons Attribution 4.0 International License.

DOI : 10.24297/jap.v13i8.6303 